\title{
In vitro evaluation of residues of coconut (Cocos nucifera L.) aqueous extracts, against the fungus Penicillium italicum
}

\author{
Héctor Javier Cortés-Rivera, Francisco Javier Blancas-Benitez, Luz del Carmen Romero-Islas, \\ Porfirio Gutiérrez-Martinez, Ramsés Ramón González-Estrada*
}

Tecnológico Nacional de México/Instituto Tecnológico de Tepic, Av. Tecnológico 2595, Col. Lagos del Country C.P. 63175 Tepic, Nayarit, Mexico

\section{A B S TR A C T}

Penicillium italicum is an important pathogen that attacks citrus fruits. Traditionally, chemical fungicides are widely used for controlling fruit diseases, however environmental and health issues have lead to the research of safe alternatives. The efficacy of aqueous extracts from mesocarp (fibrous husk) and exocarp (outer layer) of coconut were evaluated against $P$. italicum development in terms of mycelial growth, sporulation and germination process. Mesocarp extracts were more efficient to control the mycelial development (82\%) compared to exocarp extracts $(77 \%)$. The sporulation was significantly reduced with the application of extracts from mesocarp (94\%) and exocarp $(93 \%)$ compared to the control treatments. The germination process was strongly affected by the application extracts. Thus, the use of these extracts could be a suitable alternative to inhibit $P$. italicum in citrus fruit, besides the use of these residues as a source of antifungal compounds could reduce coconut residues accumulation in the environment.

Keywords: Ecofriendly; Inhibition; Fruit pathogen; Fungi development

\section{INTRODUCTION}

Coconut (Cocos nucifera L.) is one of the most widely consumed tropical fruits (Manivannan et al., 2018). Worldwide, Mexico ranks $8^{\text {th }}$ in coconut production (STATISTA, 2018). However, during the consumption of the coconut only a $20 \%$ of the fruit is used (meat and water) and the rest are considered residues (mesocarp, exocarp and endocarp), causing problems of food waste accumulation. The use of fruit residues as a source of bioactive compounds with antimicrobial properties can be an alternative. In this sense, the use of residues (peel, seed and leaf) from pomegranate (Punica granatum L.) against important pathogens such as Penicillium italicum, Rhizopus stolonifer and Botrytis cinerea have been reported (Tehranifar et al., 2011). Infections caused by phytopathogens can affect the production of several crops, leading important economic losses (Singh and Sharma, 2018). P. italicum is one of the most important pathogen that affects citrus fruit (Papoutsis et al., 2019). Traditionally, fungal control is achieved by the application of chemical fungicides (Singh and Sharma,
2018). However, there is a tendency in the use of more friendly alternatives for controlling pathogens (Reganold and Wachter, 2016). The efficacy of bioactive compounds from fruit residues is not limited for controlling fungi, these compounds have been used against several bacteria such as Listeria monocytogenes, Bacillus cereus, Eschericbia coli and Salmonella Typhimurium (Andrade et al., 2019). In a recent study, star fruit (Averrboa carambola) leaf extracts were evaluated against the fungus Colletotrichum sp. The results showed good control of the mycelial growth as well as the sporulation (Xoca-Orozco et al., 2018). The aim of this project was to investigate the in vitro antifungal activity of aqueous extracts from coconut residues against $P$. italicum.

\section{MATERIALS AND METHODS}

Raw materials

Coconut residues were visually selected on the basis of color, size and the absence of fungal infection or mechanical

\footnotetext{
${ }^{*}$ Corresponding author:

Ramsés Ramón González-Estrada, Tecnológico Nacional de México/Instituto Tecnológico de Tepic, Av. Tecnológico 2595, Col. Lagos del Country C.P. 63175 Tepic, Nayarit, Mexico. Tel.: +5213112119400 Ext. 231. E-mail: ramgonzalez@ittepic.edu.mx
}

Received: 01 April 2019; Accepted: 30 July 2019 
injury. They were obtained from a wholesale distributor in Tepic, Nayarit, Mexico and transported to the laboratory. Potato dextrose agar (PDA) (Sigma-Aldrich, USA) was used for the preparation of the nutrient media for the poisoned agar technique and Potato dextrose broth (PDB) (BD Difco ${ }^{\mathrm{TM}}$, USA) was used for the germination assay.

\section{Fungal inoculum}

The pathogen P. italicum was isolated and previously identified from decayed Persian lime (Citrus latifolia Tanaka) fruit harvested from San Pedro Lagunillas, Tepic, Mexico and stored in Petri plates containing PDA medium at $4{ }^{\circ} \mathrm{C}$ prior to the experiments.

\section{Preparation of mesocarp and exocarp aqueous extracts of coconut}

The selection parameters of the coconut fruit were size, weight and coloration of the mesocarp. Two lots of different distributors were selected. Selected samples were first washed with running water to remove impurities and solid particles, disinfected and then washed with commercial detergent $\left(\mathrm{Salvo}^{\mathrm{TM}}\right)(1.5 \% \mathrm{w} / \mathrm{v})$ and rinsed with distilled water. The samples of mesocarp and pericarp were sectioned into wedges and in individual long fibers, respectively in order to facilitate the process of moisture extraction and size reduction, using the methodology proposed by Blancas-Benitez et al. (2018) with some modifications which are observed in Fig. 1A. The samples were weighed and separated into 2 batches of $150 \mathrm{~g}$ (fresh weight) for each tissue, and then dried in a conventional oven with a digital temperature system (NOVATECH, Model: HS60 AID USA) for $24 \mathrm{~h}$ at $70{ }^{\circ} \mathrm{C}$ in aluminum trays. The dry samples were pulverized with the help of a NUTRIBULLET equipment (Model: NBR-0804B, USA) and sieved with a 0.5 micron mesh in order to obtain a homogeneous powder; the samples were stored in sealed bags at room temperature until extraction.

\section{Extraction of phenolic compounds}

The aqueous extractions from mesocarp and exocarp were carried out by the method proposed by Peréz-Jiménez et al. (2008) with some modifications, $0.5 \mathrm{~g}$ of each tissue was weighed and $25 \mathrm{ml}$ of distilled water was added to each one, and placed under stirring for $1 \mathrm{~h}$. Subsequently, samples were centrifuge for $15 \mathrm{~min}$ at $3000 \mathrm{rpm}$ (Fig. 1A). Finally, the supernatant was recovered and filtered with acrodisks (Millipore $^{\mathrm{TM}}, 0.45 \mu \mathrm{M}$ ) for in vitro assessments.

\section{Antifungal assay}

The effects of the aqueous extracts on mycelial growth inhibition as well as the sporulation were assessed by the poisoned agar technique. The extracts were added into the sterile molten agar and mixed to obtained the different concentrations to evaluate $(1,5,10 \% \mathrm{v} / \mathrm{v})$, thereafter the medium was poured into Petri dishes (Fig. 1B) (Balouiri et al., 2016).

\section{Mycelial growth}

In order to evaluated the effectiveness of treatments on mycelial development, first the fungus was grown on PDA for $7 \mathrm{~d}$ at $28^{\circ} \mathrm{C}$. Then, plugs of $10 \mathrm{~mm}$ in diameter were cut from a 6-day-old cultures. Thereafter, the plugs were placed in Petri dishes with PDA containing extracts at $1,5,10 \% \mathrm{v} / \mathrm{v}$. Plates were then incubated at $25 \pm 2{ }^{\circ} \mathrm{C}$ for 6 days, the colony diameter was registered daily. Control plates consisted in PDA without treatments. The results were reported as percentage of mycelial growth inhibition as compared to control.

\section{Sporulation}

The effect of the extracts on the sporulation process was assessed as follows: Petri dishes where mycelial growth was tested were used and briefly $10 \mathrm{~mL}$ of sterile distilled water was added to the poisoned Petri dishes. The fungal lawn was rubbed using a sterile glass rod in order to damage the mycelium and release the spores. The mycelium present in the suspension was retained through sterile cheesecloth by filtration. The spore concentration was determined by microscopic counting using a hemocytometer. Per treatment, 100 observations were made using an optical microscope (Motic BA300 Instruments Inc., Canada). The results were expressed as number of spores $/ \mathrm{mL}$.

\section{Germination}

The conidial germination was assessed as follows: $100 \mu \mathrm{L}$ of the spore suspension $\left(10^{5}\right.$ spores $\left./ \mathrm{mL}\right)$ were placed in $5 \mathrm{~mL}$ of poisoned PDB prepared with the different concentrations above mentioned $(1,5,10 \% \mathrm{v} / \mathrm{v})$. The samples were incubated at $25 \pm 2{ }^{\circ} \mathrm{C}$ for $12 \mathrm{~h}$ and observed microscopically to quantify the germinated spores. According to Yao et al. (2004) spores were considered germinated when the length of the germinative tube was at least twice the spore diameter.

\section{Statistical analysis}

A completely randomized $2 \times 3$ factorial design was carried out considering the tissue type (Exocarp and mesocarp) and the extract concentration (1, 5 and 10\% v/v). Five Petri dishes were used per replicate; all the experiments were repeated twice. ANOVA (Analysis of variance) of data was applied using Statistica Software version 10.0 for Windows. Differences between means of data were compared by LSD test, differences at $\mathrm{P}<0.05$ were considered to be significant.

\section{RESULTS AND DISCUSSION}

\section{Mycelial growth}

The mycelial growth of $P$. italicum was significantly different $(p \leq 0.05)$ among concentrations and between the types 


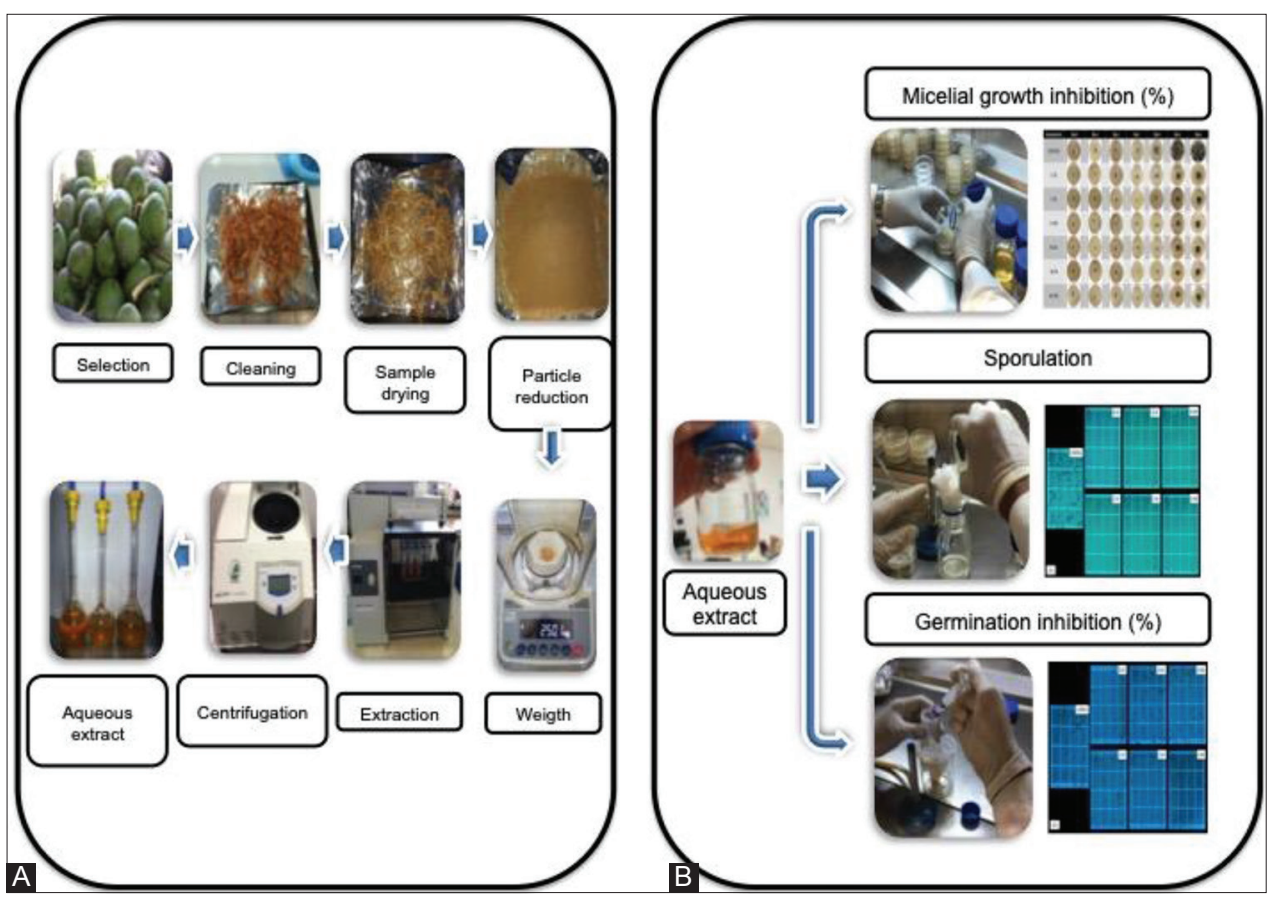

Fig 1. Methodology: A) Extraction procedure and B) In vitro assessment.

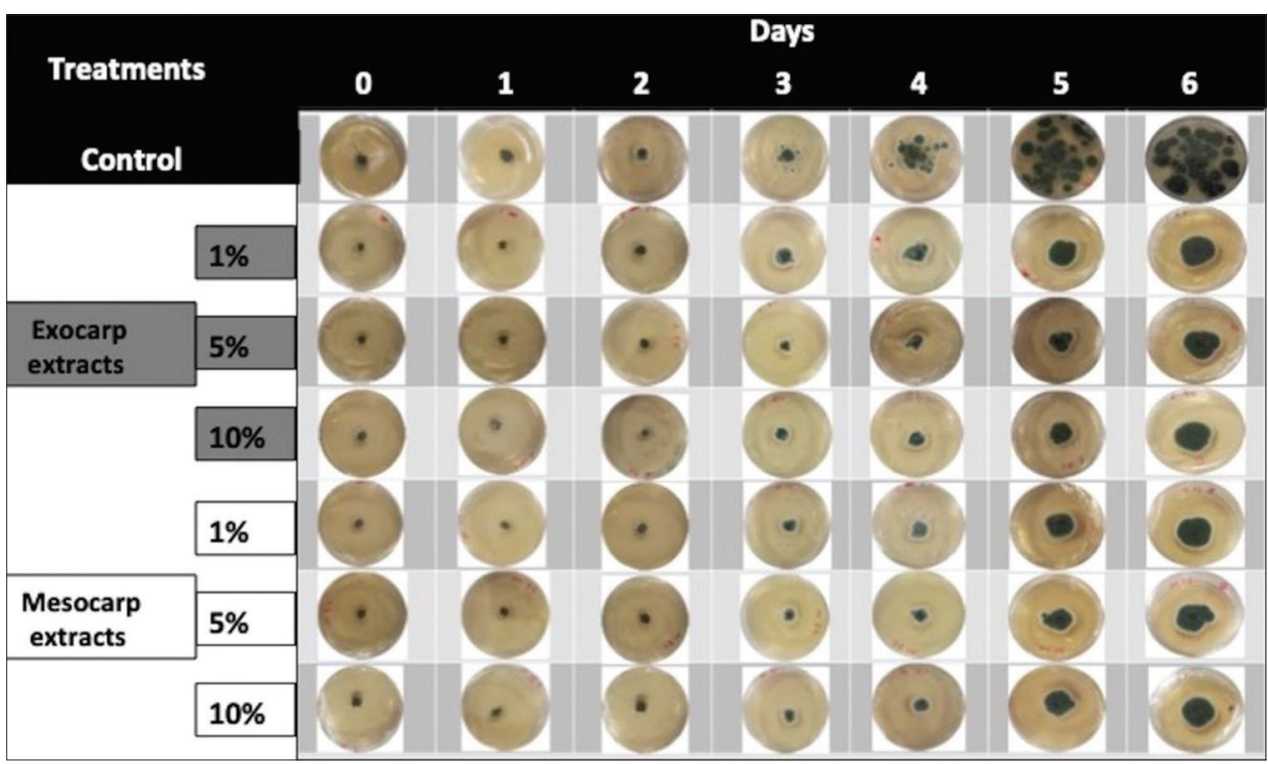

Fig 2. Effect of aqueous extracts on mycelial growth of $P$. italicum incubated for 6 days.

of extract $(\phi \leq 0.05)$ (Table 1). In general, it was observed that the mycelial inhibition was greater with the mesocarp extracts than with the exocarp ones at the concentrations of 1 and 10\% (Fig. 2). Our results are similar than other plant extracts. In this sense, Karim et al. (2017) reported the antifungal capacity of the aqueous extracts from Cistus albidus in controlling the mycelial growth of citri-aurantii $(80 \%)$ the causal agent of citrus sour rot. In a recent study, Cortés-Rivera et al. (2019) reported in extracts of coconut residues, the presence of some flavonoids including, chlorogenic acid and gallocatechin in the mesocarp, and chlorogenic acid in the exocarp. In general, the antifungal properties of phenolic compounds is related to the affectation of membrane (integrity and fluidity) affecting important biochemical processes for fungal development (Ansari et al., 2013). Chlorogenic acid can reduce the hyphal length of the necrotrophic pathogen Botrytis cinerea due to an alteration of membrane's permeabilization, as previously reported (Martínez et al., 2017). On the other hand, Mahmoud et al. (2017) reported that flavonoids can induce ultra-structural changes of mycelium like the presence of vacuoles, autophagosomes and plasmalemma distortions as 
well as structural disorganization in the cytoplasm. In this context, the greater inhibitory effect of mesocarp extracts may be due to the presence of gallocatechin a flavonoid unidentified in exocarp extracts. The results are important due to an efficient growth of hyphae plays an important role in fungal colonization of plant tissues.

\section{Germination}

In the study, all aqueous extracts were able to control de germination of P. italicum (>97\% inhibition) (Table 1). In a previous study, Karim et al. (2017) reported a significant inhibition on spore's germination (>99\%) of Geotrichum citri-aurantii by the application of Cistus albidus aqueous extracts at $0.5 \%$. In a recent investigation, Martínez et al. (2017) reported that chlorogenic acid applied at 1.5\% of concentration can affect the spore's germination process on Botrytis cinerea due to an affectation of membrane fluidity leading permeabilization that cause cell lysis.

\section{Sporulation}

There were significant differences $(p \leq 0.05)$ between the types of residues (Table 1). Overall, the mesocarp extracts were more efficient to affect the sporulation than the exocarp extracts. These results could be related with the affectation of mycelium by the presence of phenolic compounds, affecting the structures for spore's formation. In agreement with our results, Rosado-Álvarez et al. (2014) reported a reduction in the sporulation process by applying asparagus extracts against Fusarium oxysporum. Sporulation is an important event for fungal development, thus, these results are important due to a satisfactory inhibition of the sporulation that can break the infection cycle of P. digitatum on susceptible fruit to this fungus.

\section{CONCLUSIONS}

The results are important due to the application of these aqueous extracts can control the growth of P. italicum hyphae and avoid the pathogen's spread, thus these treatments can be a suitable alternative for controlling blue mold in citrus fruits. In addition, the use of residues as a source of antifungal compounds can be a smart choice for reducing coconut residues accumulation in the environment.

\section{ACKNOWLEDGEMENT}

The authors are grateful for the financial support from Tecnológico Nacional de México (TecNM) for Project 6304.19-P.

\section{Authors' contributions}

HJCR: Collection of experimental data and writing of manuscript. PGM: review of the manuscript. 
FJBB: supervision of aqueous extraction method. LCRM: statistical analysis. RRGE: supervision of the study.

\section{REFERENCES}

Andrade, M. A., V. Lima, A. S. Silva, F. Vilarinho, M. C. Castilho, K. Khwaldia and F. Ramos. 2019. Pomegranate and grape byproducts and their active compounds: Are they a valuable source for food applications? Trends Food Sci. Technol. 86: 68-84.

Ansari, M. A., A. Anurag, Z. Fatima and S. Hameed. 2013. Natural phenolic compounds: A potential antifungal agent. Microb. Pathog. Strateg. Combat. Sci. Technol. Educ. 1: 189-195.

Balouiri, M., M. Sadiki and S. Ibnsouda. 2016. Methods for in vitro evaluating antimicrobial activity: A review. J. Pharm. Anal. 6(2): 71-79.

Blancas-Benitez, F. J., J. Pérez-Jiménez, E. Montalvo-González, G. A. González-Aguilar and S. G. Sáyago-Ayerdi. 2018. In vitro evaluation of the kinetics of the release of phenolic compounds from guava (Psidium guajava L.) fruit. J. Funct. Foods 43: 139-145.

Cortés-Rivera, H. J., R. R. González-Estrada and F. J. Blancas-Benitez. 2019. Extracción e Identificación de Compuestos Bioactivos Presentes en Residuos de Coco (Cocos nucifera) Mesocarpio y Exocarpio, y su Potencial Antifúngico. México: Tecnológico Nacional de México/Instituto Tecnológico de Tepic.

Karim, H., H. Boubaker, L. Askarne, K. Cherifi, H. Lakhtar, F. Msanda, E. H. Boudyach, A. A. Aoumar and A. A. Ben. 2017. Use of Cistus aqueous extracts as botanical fungicides in the control of citrus sour rot. Microb. Pathog. 104: 263-267.

Manivannan, A., R. Bhardwaj, S. Padmanabhan, P. Suneja, K. B. Hebbar and S. R. Kanade. 2018. Biochemical and nutritional characterization of coconut (Cocos nucifera L.) haustorium. Food Chem. 238: 153-159.

Martínez, G., M. Regente, S. Jacobi, M. Del Rio, M. Pinedo and L. de la Canal. 2017. Chlorogenic acid is a fungicide active against phytopathogenic fungi. Pestic. Biochem. Physiol. 140: 30-35.
Papoutsis, K., M. M. Mathioudakis, J. H. Hasperué and V. Ziogas. 2019. Non-chemical treatments for preventing the postharvest fungal rotting of citrus caused by Penicillium digitatum (green mold) and Penicillium italicum (blue mold). Trends Food Sci. Technol. 86: 479-491.

Pérez-Jiménez, J., S. Arranz, M. Tabernero, M. E. Díaz-Rubio, J. Serrano, I. Goñi and F. Saura-Calixto. 2008. Updated methodology to determine antioxidant capacity in plant foods, oils and beverages: Extraction, measurement and expression of results. Food Res. Int. 41: 274-285.

Reganold, J. P. and J. M. Wachter. 2016. Organic agriculture in the twenty-first century. Nat. Plants 2: 15221.

Rosado-Álvarez, C., L. Molinero-Ruiz, R. Rodríguez-Arcos and M. J. Basallote-Ureba. 2014. Antifungal activity of asparagus extracts against phytopathogenic Fusarium oxysporum. Sci. Hortic. (Amsterdam). 171: 51-57.

Singh, D. and R. R. Sharma. 2018. Postharvest diseases of fruits and vegetables and their management. In: Postharvest Disinfection of Fruits and Vegetables. Elsevier, Amsterdam, Netherlands, pp. 1-52.

STATISTA. 2018. Principales Países Productores de Coco en el Mundo; 2018. Available from: https://www.es.statista.com/ estadisticas/613440/principales-paises-productores-de-cocoen-el-mundo. [Last accessed on 2019 Mar 03].

Tehranifar, A., Y. Selahvarzi, M. Kharrazi and V. J. Bakhsh. 2011. High potential of agro-industrial by-products of pomegranate (Punica granatum L.) as the powerful antifungal and antioxidant substances. Ind. Crops Prod. 34: 1523-1527.

Xoca-Orozco, L. A., V. Zamora-Gasga, G. Espinosa-Alonso, R. M. Velázquez-Estrada, U. López-García, S. Sáyago-Ayerdi and A. Chacón-López. 2018. Actividad antioxidante y antifúngica in vitro de extractos de carambola (Averrhoa carambola L.). Biotecnia. 20: 104-109.

Yao, H., S. Tian and Y. Wang. 2004. Sodium bicarbonate enhances biocontrol efficacy of yeasts on fungal spoilage of pears. Int. J. Food Microbiol. 93: 297-304. 